\title{
The Controversy Over Ukraine's New Law on Education: Conflict Prevention and Minority Rights Protection as Divergent Objectives?
}

\author{
János Fiala-Butora*
}

\begin{abstract}
This article analyses the diplomatic crisis that arose after Ukraine adopted a new Law on Education in 2017. A number of Ukraine's neighbouring countries responded negatively to the Law, arguing that it violates minority communities' right to mother tongue education. Hungary's reaction was the most serious, which led to the blocking of Ukraine's NATO and EU integration. The conflict worsened in 2018; Hungary continues to veto Ukraine's integration process, while Ukraine has put pressure on the Hungarian community in Transcarpathia. The European Commission for Democracy through Law (Venice Commission) recommended that Ukraine amend the Law, while NATO and the US called on Hungary and Ukraine to end their disagreement through bilateral negotiations. This article argues that the Law on Education does not comply with international minority rights norms ratified by Ukraine, and that the current crisis is an unfortunate consequence of the ineffective multilateral enforcement of minority rights.
\end{abstract}

Keywords

Ukraine - Hungary - Law on Education - Venice Commission - minority rights Framework Convention - NATO - securitization Introduction

In 2017, a serious conflict arose between two neighbouring countries of Central Eastern Europe when Hungary blocked Ukraine's integration process with

* Institute for Legal Studies, Centre for Social Sciences, Hungarian Academy of Sciences; Centre for Disability Law and Policy, National University of Ireland Galway.

(C) KONINKLIJKE BRILL NV, LEIDEN, 2020 | DOI:10.1163/22116117_01701011 
NATO and the European Union. On the face of it, this clash seems illogical as Hungary is a supporter of Ukraine in its conflict with Russia. Hungary's steps undermine the EU's and NATO's united stance in support of Ukraine, and effectively benefit none other than Russia, which is currently under sanctions from the EU and the US.

Hungary does, however, have a recent history of friendly relations with Russia, which has resulted in steps hostile to Ukraine in the past. ${ }^{1}$ That said, the Hungarian government has vehemently denied any allegations that, in this instance, it is acting in support of Russia. ${ }^{2}$ Instead, it has justified its actions by referring to Ukraine's adoption of the 2017 Law on Education, which limits the rights of national minorities to mother tongue education. ${ }^{3}$

In 2018, the Law on Education continued to occupy headlines and remained a topic of heated domestic and international discussions. This article describes these and connected developments, and provides an analysis of the underlying cause of the tensions around the Law on Education. It argues that the crisis is an unfortunate consequence of the lack of effective multilateral tools to enforce norms on minority rights. In this situation, states willing to act as kinstates have only blunt instruments at their disposal, which often result in bilateral conflicts. In the presence of particular factors, the conflict is likely to escalate rather than being resolved amicably.

On 5 September 2017, the Ukrainian parliament, the Verkhovna Rada, adopted a new Law on Education, which sets the general framework for all public education in the country, from pre-school to university level. ${ }^{4}$ The Law aims to modernize the educational process by bringing it into compliance with

1 Stanislava Brajerčíková and Marek Lenč, "Walking on Thin Ice: Slovak Perspective on Ukraine Crisis", 7(1) Ideology and Politics (2015), 235-256, at 242.

2 "Szijjártó: hazugság, hogy orosz megrendelés állna a magyar Ukrajna-politika mögött" [Szijj "in is a lie that there is Russian order behind the Hungarian Ukraine-policy"], Kisalföld, 27 April 2018, at <https://www.kisalfold.hu/belfold__hirek/szijjarto_hazugsag_hogy_orosz_... grendeles_allna_a_magyar_ukrajna-politika_mogott/2558350/>.

3 Tóth Tünde, "Az oktatási törvényről folytatott tárgyalás eredményei" [Results of the negotiations over the law on education], Kárpátalja.ma, 22 June 2018, at <http://www.karpatalja.ma/ karpatalja/oktatas/az-oktatasi-torvenyrol-folytatott-targyalas-eredmenyei/>.

4 Закон України “Про освіту” [Ukraine’s Law “On Education”], No. 2145-VIII, 5 September 2017, at <http://zakon2.rada.gov.ua/laws/show/2145-19/page>; an English translation is available under: European Venice Commission, Ukraine - The Law on Education adopted by the Verkhovna Rada on 5 September 2017, CDL-REF(2017)047-e, 15 November 2017. 
Western educational standards. It was immediately welcomed by the US Embassy in Ukraine as an investment in youth, key for the country's future. ${ }^{5}$

The education reform is one of many sectorial reforms Ukraine needs to undertake as part of its integration process. The Law has many positive aspects, related to modernizing the educational process in general, but these are not the object of this study. ${ }^{6}$ Besides its progressive features, the Law also includes the controversial Article 7, which changes the rules on education in minority languages, affecting many of Ukraine's minority communities. This article immediately became a source of criticism from countries neighbouring Ukraine, namely Hungary, Romania, Poland and Moldova, as well as Greece and Bulgaria. ${ }^{7}$ The tensions between Hungary and Ukraine continue to this day.

\subsection{The Context of the Law's Adoption}

To understand the controversy, one has to analyse the context of the Law's adoption from the perspective of the different parties involved. Since its independence from the Soviet Union, Ukraine has been preoccupied with the language debate, one of the most important and least successful of its nationbuilding projects. ${ }^{8}$ In Soviet times, the Ukrainian language was suppressed by the authorities and Russian was widely promoted as a de facto official language and the language of education. ${ }^{9}$ After independence, Ukrainian became the sole state language, but it has not completely eclipsed the Russian language. ${ }^{10}$ A large portion of the population, mainly in the Eastern and Southern parts of the country, still uses Russian as a means of primary communication, watches

5 Twitter account of the US Embassy in Kyiv, @USEmbassyKyiv, 1:46 AM - 10 September 2017, at <https://twitter.com/usembassykyiv/status/906801089181306880>.

6 Margarita Tulup, "Beyond the Scandal: What is Ukraine's New Education Law Really About?", Open Democracy, 8 December 2017, at <https://www.opendemocracy.net/en/ odr/ukraines-new-education-law/>.

Tomasz Daborowski, Tomasz Piechal and Andrzej Sadecki, "Ukraine: A Blow Against the National Minorities' School System”, osw - Centre for Eastern Studies, 27 September 2017, at <https://www.osw.waw.pl/en/publikacje/analyses/2017-09-27/ukraine-a-blow -against-national-minorities-school-system $>$.

8 Csilla Fedinec and István Csernicskó, “(Re)conceptualization of Memory in Ukraine after the Revolution of Dignity", 5(1) Central European Papers, (2017), 46-71.

9 Bill Bowring, "The Russian Language in Ukraine: Complicit in Genocide, or Victim of State-building?", in Lara Ryazanova-Clarke (ed.), The Russian Language Outside the Nation (Edinburgh University Press, Edinburgh, 2014), 56-80.

10 István Csernicskó, “A kétnyelvű Ukrajna” [Bilingual Ukraine], in Kornélia Hires-László (ed.), Nyelvhasználat, kétnyelvüség. Tanulmányok a Hodinka Antal Nyelvészeti Kutatóközpont kutatásaiból [Language Use, Bilingualism. Studies from the Research of the Hodinka Antal Linguistic Research Institute] (Autdor-Shark, Uzhhorod, 2016), 13-44. 
Russian media and studies in Russian.11 The other minority communities are rather negligible, but citizens declaring Russian ethnicity still make up 17.3\% of the population, and approximately $30 \%$ of the population consider Russian their mother tongue. ${ }^{12}$

Successive Ukrainian governments have adopted laws suppressing or favouring minority languages, depending on their pro-Russian or anti-Russian stance. ${ }^{13}$ Ukraine also ratified the Framework Convention for the Protection of National Minorities (FCNM) and the European Charter for Regional or Minority Languages (ECRML), ${ }^{14}$ which paradoxically led to the lowering of language standards for minorities, as the implementing legislation replaced a previous language law, which had been more favourable to minorities. ${ }^{15}$ Since 2000, several laws limiting the use of minority languages in public administration, media, culture ${ }^{16}$ and education have been adopted. ${ }^{17}$ The 2010 presidential elections were won by Viktor Yanukovych, a pro-Russian candidate, and his supporters won the 2012 parliamentary elections as well. ${ }^{18}$ The newly formed government adopted the 2012 Language Law, ${ }^{19}$ which strengthened the position of the Russian language, but was strongly opposed by nationalist forces, ${ }^{20}$

\footnotetext{
$11 \quad$ Ibid.

12 István Csernicskó, Államok, nyelvek, államnyelvek. Nyelvpolitika a mai Kárpátalja területén (1867-2010) [States, Languages, State Languages. Language Policy on the Territory of Current Transcarpathia] (Gondolat Kiadó, Budapest, 2013), 240-243.

13 István Csernicskó and Csilla Fedinec, "Four Language Laws of Ukraine", 4 International Journal on Minority and Group Rights (2016), 560-582.

14 Bill Bowring and Myroslava Antonovych, "Ukraine's Long and Winding Road to the European Charter for Regional or Minority Languages”, in Robert Dunbar (ed.), The European Charter for Regional or Minority Languages: Legal Challenges and Opportunities (Council of Europe, Strasbourg, 2008), 157-182.

15 Bill Bowring, "International Standards and Obligations, and Ukrainian Law and Legislation", in Julianne Besters-Dilger (ed.), Language Policy and Language Situation in Ukraine: Analysis and Recommendations (Peter Lang, Frankfurt am Main, 2009), 57-100.

16 István Csernicskó, "Ukrajna nyelvi helyzete egy amerikai film szinkronja tükrében” [The State of Ukraine's Languages through the Lenses of Translation of an American Movie], 1 Fórum Társadalomtudományi Szemle (2014), 93-104.

17 István Csernicskó and Viktória Ferenc, "Education as an Ideal Means of Achieving a Nation State in Ukraine”, in Jolán Róka (ed.), Concepts \& Consequences of Multilingualism in Europe (Budapest College of Communication and Business, Budapest, 2010), 329-349.

18 Bill Bowring, "Law in a Linguistic Battlefield: The Language of the New State Versus the 'Language of the Oppressors' in Ukraine", 1 International Journal of Language and Law (2012), 87-105.

19 Закон України "Про засади державної мовної політики" [Law of Ukraine "On the Principles of State Language Policy"], No. 5029-VI, o3 July 2012.

20 István Csernicskó and Csilla Fedinec, "Nyelvpolitika határon: a 2012-es ukrajnai nyelvtörvény elő- és utóéletéről” [Language Policy on the Borders: Build-up and Follow-up
} 
and also criticized by the European Commission for Democracy through Law (Venice Commission). ${ }^{21}$ This government was overthrown by a second wave of protests known as Euromaidan in 2014 and replaced by a Western-oriented government, which was more antagonistic towards Russia and less supportive of the interests of the Russian community in Ukraine. One of the new parliament's first steps, as an expression of anti-Russian sentiment, was to repeal the 2012 Language Law. This repeal did not, however, enter into force, as it was not signed by the parliamentary chair, Oleksandr Turchynov, due to domestic and international protests. ${ }^{22}$

The 2014 Euromaidan protests led to serious conflict within Ukraine and between Ukraine and its powerful neighbour, Russia. ${ }^{23}$ In 2014, Russian forces occupied the Crimean Peninsula, which has an ethnic Russian majority. Russia later annexed Crimea after a local referendum, internationally condemned as invalid, supported this step. ${ }^{24}$ Two Eastern regions with an ethnic Russian majority in the Donetsk and Luhansk oblasts also declared independence from Ukraine and started an armed struggle against the central government, with Russia's support. ${ }^{25}$

The 2017 Law on Education was adopted in the context of these geopolitical struggles. Ukraine is currently in open conflict with Russia. As part of the struggle, the government wishes to limit Russian influence, including in education and the media. Russia has, in fact, exerted considerable influence over Russian-speaking populations of the former Soviet Union through Russian-speaking and Kremlin-friendly media. ${ }^{26}$

to the 2012 Ukrainian Language Law], in Anita Márku and Kornélia Hires-László (eds.), Nyelvoktatás, kétnyelvüség, nyelvi tájkép. Tanulmányok a Hodinka Antal Nyelvészeti Kutatóközpont kutatásaiból [Teaching of languages, bilingualism, linguistic landscape. Studies from the research of the Hodinka Antal Linguistic Research Institute] (AutdorShark, Uzhhorod, 2015), 206-238.

21 Venice Commission, Ukraine - Opinion No. 605/2010 on the Draft Law on Languages in Ukraine, CDL-AD(2011)oo8, 30 March 2011.

22 István Csernicskó, Nyelvpolitika a háborús Ukrajnában [Language Policy in Wartime Ukraine] (Autdor Shark, Uzhhorod, 2016), 120-124.

23 Sergey Sayapin and Evhen Tsybulenko (eds.), The Use of Force against Ukraine and International Law: Jus Ad Bellum, Jus In Bello, Jus Post Bellum (Asser Press/Springer, The Hague, 2018).

24 Paul D’Anieri, "Gerrymandering Ukraine? Electoral Consequences of Occupation", East European Politics and Societies and Cultures (2018), 1-20.

25 Ibid.

26 Triin Vihalemm and Anu Masso, "(Re)Construction of Collective Identities after the Dissolution of the Soviet Union: The Case of Estonia", 35(1) Nationalities Papers (2007), 71-91. 
From the perspective of minority communities, however, the context is different. Ukraine is in a conflict with Russia, but its steps limiting Russian influence are affecting its own citizens, many of whom are not responsible for and do not sympathize with the Russian government's actions. This is especially pronounced for non-Russian minorities who might genuinely support Ukraine in its pro-Western and anti-Russian orientation, but are nevertheless subject to conditions limiting their rights.

From the perspective of minorities, the curtailment of mother tongue education is just another step in a longer series of attacks on their educational establishments. In fact, turning mother tongue education into bilingual education in Ukraine was already proposed in 2008, although unsuccessfully at that time. ${ }^{27}$ Subsequent governments made several steps to limit mother tongue education, for example by requiring the passing of school-leaving exams in Ukrainian as a precondition of university admission, which has severely affected graduates of minority schools. ${ }^{28}$

Not all minority communities are equally affected by alterations in policies in minority education. Members of some communities, such as Poles or Belarusians, are largely linguistically assimilated. The majority of them have Ukrainian or Russian as mother tongue, and there are very few schools teaching in their languages. On the other hand, Hungarians and Romanians are almost entirely Hungarian- and Romanian-speakers, with an established network of schools teaching through the medium of their languages. ${ }^{29}$

As one of the most linguistically separate communities in Ukraine, the Hungarian minority is particularly affected by the new policies. According to the last census, held in 2001, 156,000 Hungarians lived in Ukraine, concentrated in the Western part of the country, in Zakarpatya Oblast (Transcarpathia), on the border with Hungary. Almost half the Hungarians in Ukraine live in practically monolingual Hungarian communities, and an additional 28 per cent live in settlements where they constitute an absolute or relative majority. ${ }^{30}$ Since

27 István Csernicskó and Viktória Ferenc, "Education as an Ideal Means of Achieving a Nation State in Ukraine” in Jolán Róka (ed.), Concepts \& Consequences of Multilingualism in Europe (Budapest College of Communication and Business, Budapest, 2010), 329-349.

28 ACFC, Fourth Opinion on Ukraine - adopted on 10 March 2017, ACFC/OP/IV(2017)002, Strasbourg, 5 March 2018, para. 159.

29 Csilla Fedinec and István Csernicskó, “A 2017-es ukrajnai oktatási kerettörvény: a szöveg keletkezéstörténete és tartalma” [The 2017 Ukrainian Law on Education: The Text's History of Adoption and its Content], 25(3) Regio (2017), 278-300, 281.

30 József Molnár and István D. Molnár, Kárpátalja népessége és magyarsága [Population and Hungarians of Transcarpathia] (Association of Hungarian Teachers in Transcarpathia, Berehove, 2005), 35 . 
2001, their numbers have fallen significantly due to emigration. According to one detailed study, in 2017 there were 131,000 Hungarians in Transcarpathia, down from the 2001 census. ${ }^{31}$ Over $75 \%$ of Hungarian pupils attend schools with Hungarian as the language of instruction. ${ }^{32}$ The community has a developed education system encompassing all types of schools, from nurseries to a private university, financially supported by the Hungarian government. ${ }^{33}$

\subsection{Article 7 of the Law on Education}

Article 7 of the Law on Education declares Ukrainian as the language of instruction in the country. ${ }^{34}$ Other languages besides Ukrainian can be used in schools, depending on the communities of speakers. The Law is most generous towards indigenous peoples of Ukraine, whose languages can be used in preschools, primary (grades one to four) and secondary schools (grades five to twelve). The largest indigenous community in Ukraine is the Crimean Tatars, who mainly reside in Crimea, which is currently not under Ukrainian jurisdiction. ${ }^{35}$ The Crimean Tatars have no schools in the remaining territory of Ukraine and thus the Law has only symbolic relevance to them.

The Russian community is the most severely affected by Article 7. The Law allows Russian to be used in pre-school and primary school education, but from the $5^{\text {th }}$ grade it must be replaced by Ukrainian. Only the Russian language and Russian literature can be taught in Russian. If implemented, this provision would result in the abolition, and Ukrainization, of 621 Russian language schools, where $9.6 \%$ of the school population currently studies. ${ }^{36}$ The Law would also forbid Russian-language education in universities.

31 "Hány magyar van Kárpátalján?" [How many Hungarians are there in Transcarpathia?], Kárpátalja, 14 June 2018, at <https://www.karpataljalap.net/2018/o6/14/hany-magyar-van -karpataljan>.

32 Com. Ex. ECrmL, Third Periodic Report of Ukraine on Implementation of the European Charter for Regional or Minority Languages, MIN-LANG (2016) PR 1, Strasbourg, 12 January 2016, 193-194.

33 Primary schools are funded from the Ukrainian state budget, receiving additional financial support from Hungary; the university is funded entirely from Hungarian sources.

34 Article 7(1) of the Law on Education, op. cit., note 4.

35 Bill Bowring, "Who Are the 'Crimean People' or 'People of Crimea'? The Fate of the Crimean Tatars, Russia's Legal Justification for Annexation, and Pandora's Box”, in Sergey Sayapin and Evhen Tsybulenko (eds.), The Use of Force Against Ukraine and International Law: Jus Ad Bellum, Jus In Bello, Jus Post Bellum (The Hague, Asser Press /Springer, 2018) 21-40.

36 Com. Ex. ECRmL, Third Periodic Report of Ukraine on Implementation of the European Charter for Regional or Minority Languages, MIN-LANG (2016) PR 1, Strasbourg, 12 January 2016, 193-194. 
National minorities whose language is an official EU language represent a middle category between the above two. ${ }^{37}$ Their languages can be used as medium of instruction up until grade four. From grade five, one or more disciplines can be taught in official EU languages alongside Ukrainian. This exception related to EU languages was inserted into the Law before the final vote to appease domestic national minorities whose kin-states are EU member states.

\subsection{International Reactions to the Law on Education in 2017}

Article 7 of the Law on Education was met with strong criticism from some of Ukraine's neighbouring countries. These states, which are kin-states for their co-ethnic minorities in Ukraine, include Hungary, Romania, Russia, Poland, Moldova, as well as Greece and Bulgaria. ${ }^{38}$ They protested, stating that Article 7 diminishes the rights of minorities in Ukraine to have an education in their mother tongue. ${ }^{39}$

Ukraine initiated diplomatic consultations with the affected countries and some of them withdrew from their initial critical position. Diplomatic agreements were reached with Poland ${ }^{40}$ and Bulgaria, ${ }^{41}$ which stated that the Law on Education was to be implemented in consultation with these countries and the affected communities. The agreement with Poland also specified how the Law is to be interpreted with regard to education in Polish: in secondary schools, $60 \%$ of the curriculum will be taught in Ukrainian, and $40 \%$ in Polish. ${ }^{42}$ Romania strongly protested initially, adopting a parliamentary resolution expressing deep concerns about the Law, and even cancelling a presidential visit to Ukraine in October $2017,{ }^{43}$ but then started negotiations on the

37 This in practice includes all national minorities except Russians, placing Russians in a separate category of their own.

38 Daborowski, op. cit., note 7, 2.

39 Alya Shandra, "Ukraine's New Education Law Unleashes International Storm over Minority Language Status", EuroMaidan Press, 19 September 2017, at <http://euromaidanpress .com/2017/og/19/ukraines-new-education-law-causes-international-storm-over-minority-language-status/>.

40 "Poland and Ukraine Reach Agreement on Language of Education for National Minorities", UAWire, 24 October 2017, at <https://uawire.org/poland-and-ukraine-reach-agree ment-on-language-of-education-for-national-minorities $>$.

41 "Ukraine, Bulgaria Agree on Language Provisions of Education Law", UNIAN, 26 April 2018, at <https://www.unian.info/politics/10096481-ukraine-bulgaria-agree-on-languageprovisions-of-education-law.html >.

42 "Ukraine, Poland to Sign Declaration Implementing Language Clause of Education Law", Interfax Ukraine, 18 October 2017, at <https://en.interfax.com.ua/news/general/455691 .html>.

43 Alya Shandra, "Experts Weigh in on Ukraine's Hotly Debated New Minority Language Policy", EuroMaidan Press, 29 September 2017, at <http://euromaidanpress.com/2017/og/29/ is-the-international-tempest-over-language-in-ukraines-education-law-justified/>. 
Law's implementation. ${ }^{44}$ To date no agreements have been formalized in the shape of international treaties which would be binding upon Ukraine.

Hungary's reaction was the harshest of all the affected countries. On $20 \mathrm{Sep}-$ tember 2017, the Hungarian National Assembly unanimously adopted a resolution condemning the Ukrainian law. ${ }^{45}$ On 26 September, the Hungarian Minister of Foreign Affairs declared that the country would block Ukraine's accession process to the EU and NATO unless the Law was repealed. ${ }^{46}$ This uncompromising stance was met with criticism both from Ukraine and international commentators, accusing Hungary of furthering Russia's interests by jeopardizing Ukraine's cooperation with NATO, and pursuing its own imperialistic goals by exercising control over the Hungarian minority in Ukraine and the territory where its members reside. ${ }^{47}$

The conflict became even more a matter of international concern when, on 12 October 2017, the Parliamentary Assembly of the Council of Europe (PACE) adopted a resolution criticizing Ukraine for the Law on Education's effect on education in minority languages. ${ }^{48}$ It recommended that Ukraine modify the Law on Education by fully implementing the forthcoming recommendations of the Venice Commission. ${ }^{49}$

\section{$2.4 \quad$ The Venice Commission's Opinion}

The Venice Commission's opinion on the Law was of particular importance in the conflict, and so deserves special attention in this analysis. Ukraine requested the Venice Commission to prepare an opinion on the Law on 29 September 2017, shortly after it was adopted by the Verkhovna Rada and the relationships with neighbouring countries became strained. The Commission delivered its opinion on 11 December $2017 .{ }^{50}$ It acknowledged that promoting the state

44 "Ukraine, Romania Agree to Seek Compromise on Education Law", UNIAN, 13 April 2018, at <https://www.unian.info/politics/10079624-ukraine-romania-agree-to-seek-compromise-on-education-law.html $>$.

45 Parliament of Ukraine, 14/2017. (IX. 20.) OGY határozat a jogtipró ukrán oktatási törvény elítéléséről és az ellene való fellépésről [Parliamentary resolution on the condemnation and steps against the Ukrainian Law on Education], 26 September 2017, Hungary.

46 “Hungary Pledges 'to Deal a Painful Blow' to Ukraine's Future”, LB.ua, 26 September 2017, at <https://en.lb.ua/news/2017/og/26/4575_hungary_pledges_to_deal_painful.html>.

47 Chris Harris, "Hungary's Language Row with Ukraine is about 'sucking up to Russia”, Euronews, 19 February 2018, at <https://www.euronews.com/2018/02/19/hungary-s-language -row-with-ukraine-is-about-sucking-up-to-russia->.

48 PACE, Resolution 2189(2017) The New Ukrainian Law on Education: A Major Impediment to the Teaching of National Minorities' Mother Tongues, 12 October 2017.

49 Ibid., para. 15.

50 Venice Commission, Ukraine - Opinion no. 902/2017 on the Provisions of the Law on Education of 5 September 2017, CDL-AD(2017)030, 11 December 2017. 
language represented a legitimate interest, but stated that criticism of the Ukrainian government over the means chosen to do so was justified. ${ }^{51}$ The Commission was critical of the lack of consultation with minority communities, the lack of guarantees in the Law and its problematic wording, which gives wide scope for limiting education in minority languages. ${ }^{52}$ It considered the restrictions placed on the Russian language discriminatory and recommended amending Article 7.53 With regard to national minority languages, the Commission considered the amendment of the Law an appropriate solution. ${ }^{54} \mathrm{Nev}-$ ertheless, it suggested that many of the concerns could also be immediately addressed by implementing legislation which would ensure a sufficient level of teaching in minority languages and, at the same time, improve the quality of teaching of the state language. ${ }^{55}$ Although the Venice Commission did not specify what would constitute a 'sufficient level' of teaching in minority languages, it was made clear that the Law must address the concerns expressed in the opinion.

On 18 February 2018, Ukraine adopted a document outlining its position on implementing the Venice Commission's opinion. ${ }^{56}$ It does not entertain the possibility of amending the Law on Education. Rather, Ukraine decided to implement it through another law on secondary education to be adopted in 2019, which will divide different linguistic communities into different categories. Indigenous groups will have the most generous options for mother tongue education and could be taught in their mother tongue for up to $90 \%$ of teaching time. ${ }^{57}$ Minority communities with an EU official language will be taught in their languages 60 to $80 \%$ of teaching time at lower secondary schools, and up to $40 \%$ in upper secondary schools. ${ }^{58}$ The remaining minority languages will be taught in their language up to $20 \%$ of the time. ${ }^{59}$

The document confirms that Ukraine is in fact aiming to limit education in minority languages. Taken out of context, $80 \%$ of teaching in Romanian might sound generous, but it is certainly less than it is currently, when all subjects are

$5^{1} \quad$ Ibid., para. 119-120.

$5^{2} \quad$ Ibid., para. 120

53 Ibid., para. 124.

54 Ibid., para. 125.

55 Ibid., para. 126.

56 Ministry of Education and Science of Ukraine, Roadmap for Implementation of the Article 7 "Language of Education" of the Law of Ukraine "on Education", 14 February 2018, at $<$ https://mon.gov.ua/storage/app/media/news/Новини/2018/o2/13/broshure-road mapeng12-02-2018-1.pdf>.

57 Ibid., Annex 1, para. 6.

$58 \quad$ Ibid., Annex 1, para. 7.

59 Ibid. 
taught in Romanian except the Ukrainian language. Another document issued by the Ukrainian government also confirms that the state is aware that the reduction will be detrimental to minority cultures. It justifies its current offer for indigenous groups based on the fact that their cultures are in particular need of protection, since they only exist in Ukraine and do not have a kin-state. ${ }^{60}$ That is true, but it follows that the government is aware that a less generous language regime will be limiting other communities' options for preserving their culture - a solution justified in the eyes of the government by the fact that these cultures are present elsewhere and thus their shrinking or disappearance in Ukraine is not of concern.

\section{Developments in 2018}

\subsection{International Bodies' Reactions to the Law on Education}

On 5 March 2018, the Council of Europe (CoE) published the Advisory Committee on the Framework Convention for the Protection of National Minorities' (hereinafter ACFC or Advisory Committee) Fourth Opinion on Ukraine. ${ }^{61}$ Although it covered an earlier period, which did not take into account developments described in this article, it was quite critical of (what was then) the draft Law on Education. The ACFC noted that the draft limits education in minority languages, lowers the guarantees provided to them, and is therefore not compatible with Article 14 of the Framework Convention. ${ }^{62}$ The ACFC was also critical of the poor quality of teaching of the Ukrainian language in minority language schools, ${ }^{63}$ and the lack of accommodation of minority students in school-leaving examinations. ${ }^{64}$

The Committee of Experts on the European Charter for Regional or Minority Languages (hereinafter Com. Ex. ECRM L or Committee of Experts) adopted its Third Report on Ukraine on 24 March 2017, but published it only in December 2018. ${ }^{65}$ The Report does not consider the draft Law on Education, but is

6o Position of the Ministry of Education and Science of Ukraine Regarding the Opinion of the European Commission for Democracy through Law (Venice Commission) on the Provisions of the Law on Education of 5 September 2017, CDL-AD (2017) 030, 11 December 2017 .

61 ACFC, op. cit., note 28.

62 Ibid., para. 160.

63 Ibid., para. 157.

64 Ibid., para. 159.

65 Com. Ex. ECRML, 3rd Report of the Committee of Experts on the Application of the Charter in Ukraine, CM(2017)97, Strasbourg, 24 March 2017. 
critical of the authorities for not taking proactive steps to ensure education in minority languages. It urged the Ukrainian authorities to develop a comprehensive policy on minority language education. ${ }^{66}$

The Office of the High Commissioner for Human Rights (OHCHR) continues to monitor the human rights situation in Ukraine. Its December 2017 report contained an analysis of the Law on Education, and concluded that it was more restrictive than the previous education law, ran contrary to Ukraine's international obligations, discriminated against minority communities, and may result in increased tensions. ${ }^{67}$ In its March 2018 report, the OHCHR cited the Venice Commission's opinion on the Law on Education, noting that it reflects concerns previously raised by OHCHR. ${ }^{68}$ The EU also monitors human rights developments in Ukraine. On 9 July, the 2oth EU-Ukraine summit took place in Brussels, reviewing Ukraine's integration efforts. The joint statement emphasized the need to respect minority rights already exercised in Ukraine under relevant international conventions, and to implement the Venice Commission's recommendations. ${ }^{69}$

\subsection{Diplomatic Tensions between Hungary and Ukraine}

Ukraine is currently in the process of implementing the Venice Commission's recommendations. At the same time, it remains in an open dispute with Hungary, which is blocking Ukraine's integration with NATO and the EU until the Law is amended in a way that the Hungarian government considers to respect the right to education in minority communities' mother tongues.

On 14 February 2018, the Ukrainian Ministry of Education invited representatives of the Transcarpathian Hungarian community to discuss the Law on Education. Before the meeting, it transpired that the ministry wished to discuss the implementation of the Law through the law on secondary education further limiting education in minority languages, and thus ignoring the recommendations of the Venice Commission. ${ }^{70}$ Representatives of the Hungarian community declared that unacceptable and boycotted the meeting in protest.

\section{$66 \quad$ Ibid., paras. 18-19.}

67 Office of the UNHCHR, Report on the human rights situation in Ukraine 16 August to 15 November 2017, 12 December 2017, paras. 155-160.

68 Office of the UNHCHR, Report on the human rights situation in Ukraine 16 November 2017 to 15 February 2018, 19 March 2018, para. 136.

69 Joint statement following the 2oth EU-Ukraine Summit, Brussels, 9 July 2018, at <https:// www.consilium.europa.eu/media/36o86/joint-statement-eu-ua-summit-2018.pdf>.

70 Pallagi Marianna, "Miniszteri csúsztatás vagy provokáció? A kárpátaljai magyar szervezetek nyilatkozata az elmaradt miniszteri találkozó kapcsán” [Ministerial untruth or provocation? Statement of Transcarpathian Hungarian organizations on the missed 
Hungary blocked the meeting of the NATO-Ukraine Commission at the ministerial level in February, ${ }^{71}$ and April 2018. ${ }^{72}$ Since Hungary was alone in its position, it received criticism from other NATO members, which considered the issue of minority rights to be outside NATO's remit. ${ }^{73}$ In May, Poland called on NATo to intervene in the Hungarian-Ukrainian conflict. ${ }^{74}$ Secretary General Jens Stoltenberg called upon the two parties to find a solution through negotiation, reconciling the protection of minority rights and Ukraine's goal of promoting its national language. ${ }^{75}$ The US also intervened in the same vein. ${ }^{76}$

The parties finally met on 22 June in Uzhhorod, Ukraine, represented by ministers of foreign affairs and ministers of education. It became clear they had a very different perception of the goals and results of the meeting. The Ukrainian side considered it a breakthrough in bilateral relations, and a sign that Hungary had finally accepted the Law on Education and was now willing to negotiate its implementation. ${ }^{77}$ On the other hand, the Hungarian Minister of Foreign Affairs declared that the Law was still unacceptable to Hungary, and that it would continue to block Ukraine's integration efforts until the Venice

ministerial meeting], Kárpátalja.ma, 15 February 2018, at <http://www.karpatalja.ma/ karpatalja/nezopont/miniszteri-csusztatas-vagy-provokacio-a-karpataljai-magyarszervezetek-nyilatkozata-az-elmaradt-miniszteri-talalkozo-kapcsan/>.

71 "Hungary Once Again Blocking Ukraine-NATo Commission", UNIAN, 23 April 2018, at <https://www.unian.info/politics/10091873-hungary-once-again-blocking-ukraine-nato -commission.html>.

"Ambassador: Meeting of UA-NATO Commission 'depends on Hungary and the whole Alliance", UNIAN, 27 April 2018, at < chttps://Www.unian.info/politics/10098083-ambassador-meeting-of-ua-nato-commission-depends-on-hungary-and-the-whole-alliance .html>.

73 "Lithuania and Canada Oppose Hungarian Initiative to Revise NATo's Cooperation with Ukraine", UAwire, 27 May 2018, at <https://www.uawire.org/lithuania-and-canada -opposed-the-hungarian-initiative-to-revise-nato-s-cooperation-with-ukraine >.

"Polish FM Calls on NATO's Stoltenberg to Intervene in Hungary-Ukraine Row", UNIAN, 27 May 2018, at <https://www.unian.info/politics/10132220-polish-fm-calls-on-nato-s-stol tenberg-to-intervene-in-hungary-ukraine-row.html>.

75 "Stoltenberg Hopes Ukraine, Hungary Able to Find Solution in Language Row", UNIAN, 29 May 2018, at <https://www.unian.info/politics/10133093-stoltenberg-hopes-ukraine-hungary-able-to-find-solution-in-language-row.html>.

76 "Szijjarto Hails U.S. Role in Efforts to Settle Hungary-Ukraine Language Row", UNIAN, 31 May 2018, at <https://www.unian.info/politics/10136486-szijjarto-hails-u-s-role-in-effortsto-settle-hungary-ukraine-language-row.html>.

77 "A magyar-ukrán miniszteri találkozó médiavisszhangja" [Media reactions to the Hungarian-Ukrainian ministerial meeting], Kárpátalja, 23 June 2018, at <www.karpataljalap .net/?q=2018/o6/23/pozitiv-magyar-ukran-kormanykozi-munkacsoport-talalkozojanakukran-visszhangja $>$. 
Commission's recommendations were implemented. ${ }^{78} \mathrm{He}$ also mentioned three specific conditions which Ukraine should meet in order for negotiations to continue: limiting the Law's scope so that it does not affect private schools, prolonging the time period up to 2023 for the linguistic requirements to enter into force, and beginning negotiations with the affected minority communities about their education needs. The Ukrainian delegates agreed to these conditions, ${ }^{79}$ but whether the government is in a position to implement them remains doubtful. The first two require amending the Law, which is within the remit of members of parliament. As the three conditions had not been met, Hungary continued to block meetings of the NATO-Ukraine Commission, but did not object to President Poroshenko's attendance at the following NATO summit, which took place on 11 and 12 July. ${ }^{80}$ The Summit's Declaration urged Ukraine "to fully implement the recommendations and conclusions of the Opinion of the Venice Commission". ${ }^{81}$

On 11 July, the Ukrainian authorities held a meeting with representatives of Hungarians from Transcarpathia to implement the Venice Commission's requirement of negotiating with the affected minorities. ${ }^{82}$ They did not achieve a breakthrough. The Hungarian side wanted to discuss the implementation of the Venice Commission's recommendations, while the Ukrainian side considered the Law on Education unchangeable and wanted to discuss implementing

78 Tóth Tünde, “Az oktatási törvényről folytatott tárgyalás eredményei” [Results of the negotiations over the Law on Education], Kárpátalja.ma, 22 June 2018, at <http://www.karpatalja.ma/karpatalja/oktatas/az-oktatasi-torvenyrol-folytatott-targyalas-eredmenyei/>.

79 Molnár Krisztina, "Klimkin: Magyarországon kezdik érteni, hogy Ukrajna nem akarja diszkriminálni a magyar kisebbséget” [Klimkin: They start to understand in Hungary that Ukraine does not want to discriminate the Hungarian minority], Kárpátalja.ma, 28 June 2018, at <http://www.karpatalja.ma/karpatalja/nezopont/klimkin-magyarorszagon -kezdik-erteni-hogy-ukrajna-nem-akarja-diszkriminalni-a-magyar-kisebbseget/> .

8 o "Hungary Agrees to Ukraine's Participation in NATo Summit, but Keeps Blocking Bilateral Commission", UNIAN, 22 June 2018, at <https://www.unian.info/politics/10162691-hungary -agrees-to-ukraine-s-participation-in-nato-summit-but-keeps-blocking-bilateral-commission.html>.

81 Brussels Summit Declaration, Issued by the Heads of State and Government participating in the meeting of the North Atlantic Council in Brussels 11-12 July 2018, NATO Press Release, 11 July 2018, para. 66, at <https://www.nato.int/cps/en/natohq/official_texts _156624.htm>.

82 Pallagi Marianna, "Újabb magyar-ukrán tárgyalás Kijevben lényeges fejlemények nélkül” [Another Hungarian-Ukrainian meeting in Kyiv without important developments], Kárpátalja.ma, 11 July 2018, at <http://www.karpatalja.ma/karpatalja/kozelet/ujabb-magyar -ukran-targyalas-kijevben-lenyeges-fejlemenyek-nelkul/>. 
legislation on secondary education. ${ }^{83}$ As the latter explained, the implementing law would have to be adopted within the general framework of the Law on Education, accepting the limitations on minority languages. ${ }^{84}$

\subsection{Deterioration of Bilateral Relations and Anti-minority Incidents}

Coinciding with the gradual worsening of Hungarian-Ukrainian bilateral relations, incidents against Hungarian interests intensified in Ukraine. From the beginning of the year, local media reported several anti-Hungarian hate crimes in Transcarpathia, such as the vandalizing of Hungarian signs, cars with Hungarian license plates, and extremist anti-Hungarian rallies. ${ }^{85}$ The most serious were an arson and later a bomb attack against the Transcarpathian Hungarian Cultural Association's headquarters in Uzhhorod. Some media investigations have suggested that Russian agents, exploiting the conflict, were behind some of these attacks. ${ }^{86}$

In June 2018, the Ukrainian security agency initiated criminal proceedings for separatism against a Hungarian development organization disbursing funds from Hungary. ${ }^{87}$ In the same month, Transcarpathia's football team won the CONIFA World Cup, a tournament for regions and peoples not officially recognized as FIFA members. The Ukrainian authorities declared this an act of separatism, and threatened team members with penalties. ${ }^{88}$ In August, Ukraine declared persona non-grata István Grezsa, a newly re-appointed Hungarian ministerial commissioner for the development of Transcarpathia; ${ }^{89}$ the

83 Pallagi Marianna, "Megjegyzések a kijevi találkozó kapcsán" [Comments on the meeting in Kyiv], Kárpátalja.ma, 12 July 2018, at <http://www.karpatalja.ma/karpatalja/nezopont/ megjegyzesek-a-kijevi-talalkozo-kapcsan/>.

84 Pallagi, op.cit., note 82.

85 Dunda György, "Magyarellenes incidensek Kárpátalján” [Anti-Hungarian incidents in Transcarpathia], Magyar idők, 19 March 2018, at <https://magyaridok.hu/kulfold/ magyarellenes-incidensek-karpataljan-2904036/>.

86 Szabolcs Panyi, Anastasiia Moroz, and Konrad Szczygieł, "Western Ukraine Burning. How RussiaSetsFiretotheEU'sExternalBorder”,Vsquare.org, 27June2018, at<https://vsquare.org/ zakarpattia-western-ukraine-burning-how-russia-sets-fire-to-the-eus-external-border/>.

87 MTI, "Szeparatizmus gyanújával indított büntetőeljárást az Egán Ede kárpátaljai alapítvány ellen az szBU" [sBU started criminal proceedings against the Transcarpathian Ede Egán Foundation with suspicion of separatism], Webrádió, 5 June 2018, at <https:// webradio.hu/hirek/kulfold/szeparatizmus-gyanujaval-inditott-buntetoeljarast-az-egan -ede-karpataljai-alapitvany-ellen-az-szbu>.

88 Ráti József, "Balhéznak az ukránok a kárpátaljai világbajnokok miatt” [Ukrainian row over Transcarpathian world champions], Index, 12 June 2018, at <https://index.hu/sport/ futball/2018/06/12/ukrajna_karpatalja_vilagbajnok_szeparatizmus/ >.

89 MTI, "Ukrajna ellenséget lát abban, akitől a segítséget kapja" [Ukraine sees an enemy from whom it receives help], Kárpátinfo.net, 3 August 2018, at <https://www.karpatinfo. 
Ukrainian government considered his title an interference in Ukraine's domestic affairs. In September, Ukraine expelled the Hungarian consul in Berehove for giving out Hungarian citizenship to applicants in the region. ${ }^{90}$ The latter step was surprising because Hungary had been openly granting citizenship to Hungarians in Transcarpathia since 2010. Hungary reacted by expelling a Ukrainian consul from Hungary. ${ }^{91}$ Transcarpathian-Hungarian public officials and activists complained of harassment by the authorities, which held them up for up to eight hours at border crossing points with no reasons given. ${ }^{92}$ The website Mirotvorec published 500 names of alleged Hungarian-Ukrainian double-agents, referred to as enemies of the nation, with their personal data. ${ }^{93}$ The authorities declined to intervene, ${ }^{94}$ yet took steps to investigate whether those persons on the list had violated any Ukrainian laws. ${ }^{95} \mathrm{~A}$ citizens' petition also appeared on the website of the Verkhovna Rada, collecting signatures for the deportation of Hungarians from Ukraine. ${ }^{96}$ Lastly, in October, billboards

net/cikk/kulfold/200007652-miniszterelnokseg-ukrajna-ellenseget-lat-abban-akitol -segitseget-kapja>.

90 MTI, "Kiutasíthatják Ukrajnából a beregszászi magyar konzult" [The Hungarian consul in Berehove may be expelled from Ukraine], $H V G$, 20 September 2018, at <https://hvg.hu/ vilag/20180920_kiutasithatjak_ukrajnabol_a_beregszaszi_magyar_konzult >.

91 Lovas Gergő, “Az ukrán külügy nemkívánatos személlyé nyilvánította a beregszászi magyar konzult" [The Ukrainian Ministry of Foreign Affairs declared the Hungarian consul in Berehove persona non grata], Index.hu, 4 October 2018, at <https://index.hu/kulfold/ 2018/10/04/az_ukran_kulugy_nemkivanatos_szemellye_nyilvanitotta_a_beregszaszi _magyar_konzult/>.

92 Pallagi Marianna, "Kilencórás várakoztatás az ukrán határátkelőkön - folytatódik a kárpátaljai magyarság elleni hadviselés" [Nine hour hold-up at Ukrainian border crossings the warfare against Transcarpathian Hungarians continues], Kárpátalja.ma, 21 September 2018, at <http://www.karpatalja.ma/karpatalja/kozelet/kilencoras-varakoztatas -az-ukran-hataratkelokon-folytatodik-a-karpataljai-magyarsag-elleni-hadviseles/>.

93 Iván András, “Az ukrán nacionalisták azt állítják, orosz titkosszolgálatoktól lopták a magyar útlevelek adatbázisát" [Ukrainian nationalists claim that they stole database of Hungarian passports from Russian Secret Services], Index.hu, 11 October 2018, at <https:// index.hu/kulfold/2018/10/11/az_ukran_nacionalistak_azt_allitjak_orosz_titkosszolgala toktol_loptak_a_magyar_utlevelek_adatbazisat/>.

94 MTI, "Kijev szerint hamarosan megegyezés születik a nyelvtörvényről" [According to Kyiv soon there will be an agreement about the language law], Origo, 15 October 2018, at <https://www.origo.hu/nagyvilag/20181015-klimkin-kijev-nem-akarja-asszimilalni-a -karpataljai-magyarokat.html>.

95 Thüringer Barbara, “Több száz tisztviselőt világítanak át Kárpátalján, hogy kettős állampolgárok-e" [Several hundred officials will be vetted in Transcarpathia for dual citizenship], Index.hu, 9 October 2018, at <https://index.hu/kulfold/2018/10/og/karpatalja _magyar_allampolgarsag_atvilagitas/>.

96 Mondik Márta, "Még mindig nincs uniós válasz a kárpátaljai magyarok elleni sorozatos jogsértésekre" [There is still no response from the Union on the continuous violation of the rights of Transcarpathian Hungarians], Kárpátalja.ma, 23 October 2018, at 
appeared around Transcarpathia, calling some representatives of the Hungarian community traitors and separatists. ${ }^{97}$ The Ukrainian authorities initiated criminal proceedings for the latter incident. ${ }^{98}$

The Hungarian Minister of Foreign Affairs expressed his concerns about these incidents in September ${ }^{99}$ and the parties agreed on negotiations to resolve some of the existing disputes. They found a solution to the question of the Hungarian commissioner by changing his title to make it more acceptable to the Ukrainian side. ${ }^{100}$ They also agreed to hold a consular meeting specifically on the question of dual citizenship. ${ }^{101}$ On 24 October, on a meeting of the two ministers of foreign affairs, Hungary proposed a bilateral treaty on minority protection. ${ }^{102}$ In November, Ukraine granted the acceptance letter to the new Hungarian Ambassador to Ukraine, which had been previously denied for three months. ${ }^{103}$

$<$ http://www.karpatalja.ma/karpatalja/nezopont/meg-mindig-nincs-unios-valasz-a -karpataljai-magyarok-elleni-sorozatos-jogsertesekre/>.

MTI, "Magyarellenes óriásplakátok jelentek meg Kárpátalján” [Anti-Hungarian billboards appeared in Transcarpathia], Origo, 20 October 2018, at <https://www.origo.hu/ nagyvilag/20181020-magyarellenes-oriasplakatok-jelentek-meg-karpataljan.html>.

MTI, "Magyarázkodnak az ukrán hatóságok a magyarellenes plakátok miatt" [Ukrainian authorities explain anti-Hungarian billboards], Origo, 22 October 2018, at <https://www .origo.hu/nagyvilag/20181022-nemzetisegi-viszaly-szitasa-miatt-indul-eljaras-karpataljan -a-magyarellenes-oriasplakatok-ugyeben.html>.

мті, “Kijev szerint Budapest a Moszkvával folyó tárgyalásain próbál hasznot húzni az "útlevélbotrányból"' [According to Kyiv, Budapest tries to take advantage of the 'passportscandal' in its negotiations with Moscow], Kárpátinfo.net, 23 September 2018, at <https:// www.karpatinfo.net/cikk/belfold/200011003-kijev-szerint-budapest-moszkvaval-folyo -targyalasain-probal-hasznot-huzni-az-utlevelbotranybol>.

100 The new title is "Ministerial Commissioner responsible for the development of cooperation between Szabolcs-Szatmár-Bereg county and Transcarpathia and the coordination of the program on development of childcare facilities in the Carpathian basin"; Kocsis Julianna, "Módosították Grezsa István titulusát" [István Grezsa's title was modified], Kárpátalja.ma, 30 October 2018, at <http://www.karpatalja.ma/kitekinto/magyarorszag/ modositottak-grezsa-istvan-titulusat/>.

101 "Kijev nem vitázik Magyarországgal az ukrán törvények értelmezéséról" [Kyiv does not argue with Hungary about the interpretation of Ukrainian laws], Karpatinfo.net, 26 November 2018, at <https://www.karpatinfo.net/cikk/belfold/20001482o-kijev-nem-vitazikmagyarorszaggal-az-ukran-torvenyek-ertelmezeserol>.

102 MTI, "Magyarország kisebbségvédelmi egyezmény megkötését javasolta Ukrajnának" [Hungary proposed to Ukraine to conclude a treaty on minority protection], Origo, 24 October 2018, at <https://www.origo.hu/itthon/20181024-kisebbsegvedelmi-egyezmyt -kotne-magyarorszag-ukrajnaval.html>.

103 мті, "Megkapta a befogadó nyilatkozatot az új kijevi magyar nagykövet", Mandiner, 8 November 2018, at<https://mandiner.hu/cikk/20181108_megkapta_a_befogado_nyilatkozatot _az_uj_kijevi_magyar_nagykovet>. 
After a difficult period, bilateral relations seemed to normalize. After the Kerch Strait incident of 25 November, when Russian coast guard boats fired at and captured three Ukrainian Navy vessels, Hungary declared its full support for Ukraine's sovereignty and territorial integrity. ${ }^{104}$ However, normalization did not resolve the dispute over the Law on Education. Hungary declared that it would continue to block meetings of the NATO-Ukraine Commission in December, while not opposing the participation of Ukraine in the meeting of NATo Ministers of Foreign Affairs. ${ }^{105}$ At the meeting itself, the Hungarian minister explained that Hungary had been under a lot of pressure to modify their position, but they would only do so if Ukraine restored the linguistic rights of its minority communities. ${ }^{106}$

\subsection{Adoption of the New Language Law}

Although overshadowed by discussions concerning the Law on Education, another important issue affecting minority rights in Ukraine developed in 2018. On 28 February 2018, the Constitutional Court of Ukraine declared unconstitutional the 2012 Language Law ${ }^{107}$ for procedural reasons related to its adoption. ${ }^{108}$ This law regulated the use of languages at the local and regional levels and its abolition resulted in a legal vacuum. ${ }^{109}$

The government reacted to the ruling on unconstitutionality with a bill for a new language law, which was adopted at its first reading by the Verkhovna

104 MTI, "Szijjártó: Magyarország kiáll Ukrajna területi integritása és szuverenitása mellett" [Szijjártó: Hungary supports Ukraine’s territorial integrity and sovereignty], Kárpátinfo. net, 28 November 2018, at <https://www.karpatinfo.net/cikk/kulfold/200014923-szijjarto -magyarorszag-kiall-ukrajna-teruleti-integritasa-es-szuverenitasa-mellett>.

105 MTI, "Szijjártó: Magyarország továbbra is blokkolja a NATO-Ukrajna Bizottság ülését" [Szijjártó: Hungary continues to block meetings of the NATO-Ukraine Commission], Kárpátinfo.net, 20 November 2018, at <https://www.karpatinfo.net/cikk/kulfold/200014468 -szijjarto-magyarorszag-tovabbra-blokkolja-nato-ukrajna-bizottsag-uleset>. MTI, "Magyarország figyeli Ukrajna kisebbségeket érintő politikáját" [Hungary pays attention to Ukraine's policies affecting minorities], Hirado.hu, 5 December 2018, at <https://www.hirado.hu/kulfold/kulpolitika/cikk/2018/12/04/magyarorszag-figyelemmel -koveti-ukrajna-kisebbsegeket-erinto-politikajat/>.

107 Закон України “Про засади державної мовної політики” [Law of Ukraine "On the Principles of State Language Policy"], No. 5029-VI., 03 July 2012.

108 Office of the Un HCHR, Report on the Human Rights Situation in Ukraine 16 February to 15 May 2018, 20 June 2018, para. 85.

109 "Brenzovics László: A kárpátaljai magyarság hathatósabb fellépést vár az EBEsz-től" [László Brenzovics: Transcarpathian Hungarians expect more powerful action from osCE], Kárpátalja.ma, 11 September 2018, at <http://www.karpatalja.ma/karpatalja/nezopont/ brenzovics-laszlo-a-karpataljai-magyarsag-hathatosabb-fellepest-var-az-ebesz-tol/>. 
Rada on 4 October. ${ }^{110}$ However, this bill only regulated the use of the state language, and therefore leaves minority languages in a state of legal uncertainty. ${ }^{111}$ According to an analysis by the UN Human Rights Mission in Ukraine, the proposed law raises serious concerns about its compatibility with international human rights standards, and does not offer a balanced framework to protect minority languages. ${ }^{112}$ Representatives of several minority communities expressed concerns on the draft law, ${ }^{113}$ as did the Hungarian Minister of Foreign Affairs ${ }^{114}$ and 19 Members of the European Parliament in an open letter. ${ }^{115}$ The EU asked Ukraine to request the Venice Commission for an opinion on the draft law. ${ }^{116}$

\section{Assessment of the Law on Education under the FCNM and the ECRML}

As detailed above, several international bodies have criticized the Law on Education during the period analysed. However, the ACFC and the Com. Ex. ECRML, the treaty bodies of the two most relevant instruments, have not yet

110 Bill 5670-д, Закон України "Про забезпечення функціонування української мови як державноі" [Law of Ukraine "On Ensuring the Functioning of Ukrainian as the State language"]; an English translation of the law was not available at the time of writing this article.

111 Pallagi Marianna, “Tényleg van-e új nyelvtörvény?" [Is there really a new language law?], Kárpátalja.ma, 5 October 2018, at <http://www.karpatalja.ma/karpatalja/nezopont/ tenyleg-van-e-uj-nyelvtorveny/>.

112 Office of the UNHCHR, Briefing Note on the Draft Law 'On Ensuring the Functioning of Ukrainian as the State language', 9 November 2018.

113 Pallagi Marianna, "Az ukrajnai kisebbségek oktatási helyzete került terítékre Brüsszelben" [Education of Ukrainian minorities was discussed in Brussels], Kárpátalja. $m a, 2$ December 2018, at <http://www.karpatalja.ma/karpatalja/oktatas/az-ukrajnai -kisebbsegek-oktatasi-helyzete-kerult-teritekre-brusszelben/>.

114 KKM, "Jelentősen romlott a helyezet Ukrajna vonatkozásában" [The situation with regard to Ukraine has worsened significantly], Magyar Idök, 25 October 2018, at $<$ https://magyaridok.hu/kulfold/szijjarto-peter-jelentosen-romlott-a-helyzet-ukrajna -vonatkozasaban-3608039/>.

115 MTI, "EP-képviselők egy csoportja nyílt levélben tiltakozott a tervezett ukrán nyelvtörvény ellen" [Group of MEPs protests the planned Ukrainian language law in an open letter], Kárpátinfo.net, 27 October 2018, at <https://www.karpatinfo.net/cikk/kulfold/200013105 -ep-kepviselok-egy-csoportja-nyilt-levelben-tiltakozott-tervezett-ukran-nyelvtorveny -ellen>.

116 "EU Asks Ukraine to Submit Draft of the 'Language' Law for Final Review by Venice Commission", UAWIRE, 13 October 2018, at <https://www.uawire.org/the-european-union -asks-ukraine-to-submit-a-draft-of-the-language-law-to-the-venice-commission\#>. 
had the chance to comment on it. Therefore, it is an open question as to whether the Law complies with or violates international treaties on national minorities and minority languages. The following analysis will address this issue.

The linguistic requirements of the Law on Education are quite vague when it comes to languages of national minorities. The Law stipulates that "one or more" classes per week can be taught in a minority language, which can range from one class to "every class but Ukrainian language and literature", which is the current situation. Details are to be set in specific laws regulating education on pre-school, primary-school and secondary-school levels. However, even in its current uncertain form, the Law falls below Ukraine's obligations under European treaties protecting minority rights and languages. This can be confirmed by examining how Ukraine's current policy on education in minority languages was assessed under the treaties.

The FCNM regulates minority language education in Article 14(2). It requires that persons belonging to minorities be taught the minority language or receive instruction in the minority language. Similarly, the ECRML allows states to select obligations under Article 8(1) to teach minority languages or through the medium of such languages, which Ukraine has done. Therefore, the Ukrainian government can argue that its obligations are fulfilled if it provides teaching of minority languages only, without employing them as languages of instruction. ${ }^{117}$

However, the monitoring bodies of both treaties clarified that the choice between the two models is not up to the state and that the Law must reflect the needs of the specific minorities. As the Com. Ex. ECRM L explained, minorities with a well-developed education system, such as the Hungarians, Romanians and Russians, require education in their mother tongue, which the state should provide. ${ }^{118}$ Similarly, the ACFC emphasized that "demand is a key element" in Article 14(2) of the FCNM; therefore the state must offer education in minority languages for communities which request it. ${ }^{119}$

The treaty-monitoring bodies found shortcomings under these articles with regard to several of the national minority communities that did not benefit from sufficient education in their language. The main concerns related to the

117 When ratifying the ECRML, Ukraine has chosen to apply provisions which allow to offer teaching of minority languages and teaching in minority languages alternatively: Article 8(1) a(iii), b(iv), c(iv) and d(iv).

118 Com. Ex. ECRML, 2nd Report of the Committee of Experts on the Application of the Charter in Ukraine, ECRML(2014) 3, Strasbourg, 15 January 2014, para. 110.

119 ACFC, Third Opinion on Ukraine, Advisory Committee on the Framework Convention for the Protection of National Minorities, ACFC/OP/III(2012)oo2, Strasbourg, 28 March 2013, para. 128. 
question of guarantees, as the Law did not specify who has to request, and how many requests are necessary, to open a school or class teaching in a minority language. ${ }^{120}$ It has therefore been at the discretion of the domestic regional authorities to decide whether to grant a request to six or 15 pupils, or to reject it arbitrarily, even if a large number of pupils and their parents requested that a school teaching in Romanian be opened. ${ }^{121}$ The Committee of Ministers emphasized that establishing new classes should not be the responsibility of citizens; the authorities must be proactive in mapping the demand of pupils and establish classes accordingly. ${ }^{122}$

The cited opinions of the treaty monitoring bodies were formulated with reference to Ukraine's previous education law adopted in 1991, but they apply to the 2017 Law on Education as well. It is clear that the new Law falls below the standards of the previous law in terms of linguistic rights. ${ }^{123}$ The 2017 Law guarantees education in minority languages only up to grade four. From grade five, minority language education is possible but not guaranteed. Under the previous law, education was at least formally guaranteed, although detailed guarantees were missing in practice. The 2017 Law further diminished these guarantees.

Apart from the issue of legal guarantees, the 2017 Law is also problematic from a substantive point of view. Currently, minority language schools teach all classes in their minority language except classes on Ukrainian language and literature. According to the new law, they will be able to teach "one or more" classes in the minority language. This particular formulation suggests a drive to limit the range of classes taught in minority languages. Indeed, this is how the Ukrainian government interprets it. ${ }^{124}$ The Law, therefore, means further backsliding on minority rights compared to the already criticised status quo.

Several other problems can be identified in Article 7. Education in minority languages will be possible in separate classes in schools teaching in Ukrainian, but the Law does not mention schools with a minority language

\footnotetext{
120 Ibid., para. 127.

121 Ibid., para. 113.

122 Ibid., para. 112.

123 ACFC, op. cit., note 28, para. 160.

124 Position of the Ministry of Education and Science of Ukraine Regarding the Opinion of the European Commission for Democracy through Law (Venice Commission) on the Provisions of the Law on Education of 5 September 2017 (CDL-AD (2017) 030), 11 December 2017; see also an analysis of the Ukrainian government's position in Ivan Toronchuk and Volodymyr Markovskyi, "The Implementation of the Venice Commission Recommendations on the Provision of the Minorities Language Rights in the Ukrainian Legislation", 5(1) European Journal of Law and Public Administration (2018), 54-69.
} 
of instruction. ${ }^{25}$ It is unclear what happens to those schools which currently only have classes teaching in minority languages. According to Fedinec and Csernicskó, these will lose their legal personality and independence, because only Ukrainian-language schools can exist as autonomous entities under the Law - a reading certainly in line with the Law's text. ${ }^{126}$ Similarly, the "one or more" classes of minority language instruction can take place alongside instruction in Ukrainian, not instead of Ukrainian. The logical reading, adopted by Fedinec and Csernicskó, suggests that the classes must in fact be bilingual, using both languages, in a way that is yet unclear. ${ }^{127}$ This might not have been the legislators' intent and it is only a case of unfortunate wording, but the text certainly contributes to a lack of legal clarity and further diminishes the guarantees of minority language education.

The Ukrainian government justified Article 7 of the Law by arguing that many pupils from minority language schools fail to achieve a sufficient command of Ukrainian, which limits their opportunities for higher education, and therefore schools must remedy the situation by teaching the students more classes in Ukrainian. ${ }^{128}$ This justification is both revealing and unsatisfactory. It shows that the authorities indeed plan to limit instruction in minority languages, which is the automatic consequence of teaching more classes in Ukrainian. It also reveals that they consider the choice of language a zero-sum game, where the interests of the state and those of minority speakers have to be balanced against each other.

Many speakers of minority languages do indeed have a poor command of Ukrainian, and the state has a legitimate interest in ensuring that all its citizens have a sufficient knowledge of the official language. This was accepted by the drafters of the FCNM and the ECRML as well. ${ }^{129}$ Representatives of minority communities are themselves not opposed to learning Ukrainian. Quite the contrary; for example, the Hungarian community's representatives have requested for decades that the state take measures to improve the teaching of Ukrainian in minority schools. ${ }^{130}$ In fact they complained at the international level that the state does not provide language books, dictionaries, sufficiently trained

\footnotetext{
125 See Article 7(1) of the Law.

126 Fedinec and Csernicskó, op. cit., note 29, 293.

127 Ibid.

128 "Why Ukraine Needs New Law on Education", at <http://uaedulaw.com/>.

129 See Article 14(3) of the Framework Convention and Article 8(1) of the Charter.

130 Written Comments by Hungarian Researchers and NGos in Transcarpathia (Ukraine) on the Third Periodic Report of Ukraine on the Implementation of the European Charter for Regional or Minority Languages, Berehove, 11 July 2016, p. 19, at <https://kmksz.com.ua/ wp-content/uploads/2017/o1/Ukraine-Charter-shadow-report-Arnyekjelentes-nyk.pdf >.
} 
language teachers and an appropriate methodology to achieve this task. ${ }^{131}$ The Association of Hungarian Teachers in Transcarpathia formulated a common position for the purposes of negotiations with the ministry of education, which stresses the improvement of the teaching of Ukrainian in Hungarian schools as the main objective, which the new Law on Education does not address. ${ }^{132}$

Adequate teaching of Ukrainian requires all the above methods, but it does not require teaching classes in Ukrainian apart from Ukrainian language and literature. Examples of other countries show that sufficient command of the official language can be achieved in minority language schools where the official language is taught only as a subject. ${ }^{133}$ However, the 2017 Ukrainian Law on Education provides no guarantees to improve the teaching of Ukrainian, apart from increasing the number of subjects taught in it.

Without improvements in the teaching of Ukrainian, pupils from minority communities would be doubly disadvantaged. Many of them would fail to learn Ukrainian properly, and they would also fail to make progress in the courses that are taught in Ukrainian, a language they do not sufficiently understand. The purpose of education is not simply indoctrination in a national culture, but acquiring knowledge, for which the mother tongue is still the best medium. ${ }^{134}$

For these reasons, the Ukrainian government's interest in ensuring that all citizens speak Ukrainian is certainly legitimate and is an interest that the minority communities in fact share, but this does not require and does not justify limiting education in minority languages. The state has other, more effective methods at its disposal to achieve its goal - methods which it has failed to use, despite requests from minority communities.

The Ukrainian government also justified its language policies by arguing that similar regulations affect the Ukrainian minority in neighbouring countries. This is incorrect, ${ }^{135}$ but more importantly, even if it were true, it would

131 ACFC, op. cit., note 28 , para. 157 .

132 Célok és feladatok az ukrán mint államnyelv oktatásának javítása területén [Goals and tasks for improving the teaching of Ukrainian as a state language], Association of Hungarian Teachers in Transcarpathia, 16 December 2017.

133 For example, in Slovakia, pupils in schools with Hungarian as language of instruction have a good command of Slovak even though it is only taught as a subject.

134 Stephen May, "Rearticulating the Case for Minority Language Rights", 4(2) Current Issues in Language Planning (2003), 95-125, 117.

135 Slovakia, Romania and Hungary have a system of minority language schools where education can take place entirely in minority languages. There are few schools teaching in Ukrainian compared to other minority language schools (such as Hungarian-language schools in Slovakia and Romania, and German-language schools in Hungary), but the reason for this is the small size of the Ukrainian community, not legal restrictions. 
not justify violations of Ukraine's international obligations. There certainly are countries which limit minority education rights even more severely than this particular Ukrainian law - Latvia's recent education reform is a case in point. ${ }^{136}$ But Latvia's bad example does not lower international standards; they continue to apply to Ukraine (and Latvia) in the same way.

\section{Conflict Prevention or Human Rights Promotion? - Two Natures of the Conflict}

The conflict between Hungary and Ukraine is a bilateral diplomatic and security conflict. It attracts particular attention because it jeopardized Ukraine's cooperation with NATO and thus its vital security interests in the face of Russia's illegitimate actions in Ukraine. At the same time, the conflict can also be characterised as a disagreement over human rights norms. The main object of the dispute from the Hungarian point of view is the Law on Education. Objections to it are indeed based on international human rights standards relating to the right to education of minorities. ${ }^{137}$

Nevertheless, Slovakia has schools teaching in Ruthenian (a language closely related to Ukrainian), and Romania has schools teaching in Ukrainian. See Com. Ex. ECRML, 4th Report of the Committee of Experts on the Application of the Charter in Slovakia, ECRML(2016)2, Strasbourg, 27 April 2016, para. 211; Com. Ex. ECRML, Second report of the Committee of Experts in respect of Romania, $\mathrm{CM}(2018) 4$, Strasbourg, 7 February 2018, para. 107. In Hungary, according to Jaroszlava Hartyanyi, a representative of the Ukrainian Minority in the Hungarian Parliament, there are no legal or administrative obstacles to teaching in minority languages, and several minority communities do in fact have schools teaching in their languages. However, since the Ukrainian community is small and dispersed, there are not enough pupils to open a class teaching in Ukrainian; see Kocsis Julianna, "Hartyanyi Jaroszlava: 'Ha megfelelően képzett nyelvtanárok oktatnák a magyarokat, megtanulnák az államnyelvet" [Jaroszlava Hartyanyi: "If Hungarians were taught by adequately trained language teachers, they would learn the state language"], Karpatalja. $m a$, 19 October 2017, at <http://www.karpatalja.ma/karpatalja/nezopont/hartyanyi -jaroszlava-ha-megfeleloen-kepzett-nyelvtanarok-oktatnak-a-magyarokat-megtanulnakaz-allamnyelvet/>.

136 "President Promulgates Law Leading to Latvian Language Switch in Schools", LSM.lv, 2 April 2018, at $<$ https://eng.lsm.lv/article/society/education/president-promulgates-lawleading-to-latvian-language-switch-in-schools.a273409/>.

137 This is not to say that all actions of the Hungarian government in bilateral conflicts related to Hungarian communities in neighbouring countries are based on human rights norms; see János Fiala-Butora, "Hungarians in Slovakia and the Evolution of HungarianSlovakian Bilateral Relations - Improvement or Stalemate?" 12 EYMI (2015), 158-196. Specifically with regard to Ukraine, the Hungarian government, similarly to other neighbours of Ukraine, acts extraterritorially by permitting Transcarpathian Hungarians to obtain 
Security conflicts and human rights conflicts affecting minorities often overlap, and in practice are difficult to separate analytically. In fact, there has been a convergence of instruments and bodies dealing with these types of conflicts in relation to national minorities in Europe. ${ }^{138}$ Nevertheless, human rights protection and conflict prevention approaches have different goals. If the conflict between Hungary and Ukraine were to be understood through the lens of security considerations, it would have a simple resolution - the two parties involved should come to an agreement over the extent of mother tongue education in secondary schools. The result might be less than what Hungary demands, but that is the nature of diplomacy - compromises must be made on both sides. This is indeed the position of NATO and the US, which called on Hungary and Ukraine to end their conflict through negotiations.

However, from the perspective of international human rights norms, the issue is not that simple. As the above analysis suggests, the Law is violating the right to education of minority communities. Consequently, the conflict cannot be resolved without amending the Law and bringing it into compliance with international norms. This is true even if Hungary agreed to accept the Law as it is, or even if the representatives of minority communities in Ukraine did as well. The beneficiaries of human rights norms are individuals. Any person from Ukraine might raise a claim that the Law violates their rights. Neither their local representatives, nor the Hungarian state can waive this right on their behalf. An agreement between Hungary and Ukraine would not bind an individual victim or the international bodies reviewing compliance with human rights treaties.

The evidence suggests that bilateral diplomacy will not be particularly effective in this case to guarantee the Law's amendment. Negotiations have in fact been attempted, but the parties' positions diverge too much for a solution to be found. ${ }^{139}$ The Hungarian community in Ukraine, supported by Hungary, cannot accept the Law on Education, as it runs contrary to its vital interests. The Ukrainian government, on the other hand, is not willing to amend the Law, and only wishes to discuss its implementation. In this situation, bilateral negotiations cannot achieve the goal of compliance with human rights norms. Rather, they can have the opposite result; they could legitimize the Law on Education,

Hungarian citizenship, and is also supporting Hungarian cultural associations, political parties, teachers, and businesses. However, these activities long predate the dispute over the Law on Education and cannot be considered one of its causes.

138 Merja Pentikäinen, “Social Integration of 'Old' and 'New' Minorities in Europe in Views of International Expert Bodies Relying on Human Rights: Contextual Balancing and Tailoring", 14(1) Journal on Ethnopolitics and Minority Issues in Europe (2015), 26-47.

Daborowski, op. cit., note 7 . 
which is considered unacceptable by minority communities in Ukraine, and is violating international treaties. ${ }^{140}$

Other states' negotiations can also serve as a useful reference point about the ineffectiveness of the bilateral approach. The agreements with Bulgaria, Poland and Romania did not result in an outcome that would be favourable to minorities. Indeed, the solution reached by Poland further limits minority rights, even compared to the Law on Education.

It is also questionable to what extent the Ukrainian government would be bound by any bilateral agreement. If it was later violated by a legislative provision, what value would the agreement have? The Hungarian-Ukrainian bilateral negotiations of 22 June 2018 can serve as an example. The Ukrainian representatives agreed to postpone the Law's entry into force and to take private schools out of its scope, but it is doubtful whether they would be able to pass such an amendment in the Verkhovna Rada.

The interests of minority communities would have received more attention from the Ukrainian authorities if international bodies responsible for enforcing international human rights norms had put more pressure on the country. This has so far not been the case. Ukraine has long ignored the recommendations of the CoE under the FCNM and the ECRML. Other bodies, such as the OSCE High Commissioner on National Minorities, and notably the powerful $\mathrm{EU}$, remained passive in the conflict, contributing little to its resolution. ${ }^{141}$

In this situation, there are not many options available to states seeking to promote the rights of their co-ethnics. Hungary has little leverage over Ukraine, and it is unlikely it would be more successful in bilateral negotiations than Poland or Romania were. Therefore it has chosen to engage organizations with the greatest influence on Ukraine: the EU and NATO.

This tactic is not without precedent. Denmark achieved the consolidation of the situation of the Danish minority in Germany by threatening to veto West Germany's NATO accession in $1955 \cdot{ }^{142}$ Indeed, this approach is already bearing

\footnotetext{
140 Pallagi, op. cit., note 111.

141 EU Commissioner Mogherini declined to intervene, as reported in "Mogherini válaszlevele az ukrán oktatási törvény kapcsán" [Mogherini's response concerning the Ukrainian Law on Education], Kárpátalja.ma (12 April 2018), at <http://www.karpatalja.ma/karf patalja/nezopont/mogherini-valaszlevele-az-ukran-oktatasi-torveny-kapcsan/>; also, although an osce mission visited Transcarpathia, it apparently did not discuss the Law on Education with local representatives: Mondik Márta, "Az EBEsz képviselőivel tárgyalt Beregszász polgármestere" [Berehove's mayor met with representatives of the oscE], Kárpátalja.ma, 18 October 2018, at <http://www.karpatalja.ma/karpatalja/kozelet/az-ebesz -kepviseloivel-targyalt-beregszasz-polgarmestere/>.

142 Jorgen Kühl, The National Minorities in the Danish-German Border Region, (Danish Institute of Border Region Studies: Aabenraa, Denmark, 2003), 24.
} 
fruits in the case of Hungary as Ukraine has agreed to comply, at least formally, with the Venice Commission's recommendations after being called on to do so by the NATO Secretary General, ${ }^{143}$ who would not be involved in the conflict at all without Hungary's vetoing position.

That said, it does not follow that the tactics chosen by Hungary will be successful. Bilateral negotiations with Ukraine were unfruitful, but blocking Ukraine's NATO and EU accession might ultimately prove ineffective as well. In this case, considerable harm would have done to all those involved for no good reason. It remains to be seen whether the benefits outweigh the costs.

\section{Conclusion}

The Hungarian-Ukrainian conflict is an example of how incentives to prevent conflicts created by international law can lead to unfortunate outcomes. Hungary has no special interest in undermining Ukraine's efforts to protect itself from Russia; in fact, generally speaking, Hungary's position has been to support Ukraine in its conflict with Russia. However, there is no tool at Hungary's disposal to promote the rights of its co-ethnics other than engaging the international community by threatening Ukraine's security interests.

This situation could have been avoided if the international community had been more proactive in enforcing international human rights norms related to minorities. Unfortunately, this has not been the situation in the case of the Ukrainian Law on Education. Many commentators are critical of bilateral approaches by kin-states in protecting minority rights, and for good reason. ${ }^{144}$ Kin-states are self-interested, they have a stake in the matter, their involvement leads to conflicts and can do more harm than good. But if international bodies are inactive, kin-states become the only actors seeking to enforce particular international norms on minority rights, precisely because they have a stake in the matter. Furthermore, their influence can increase if the conflict becomes more grave, because that attracts the attention of the international

143 “Polish FM Calls on NATO's Stoltenberg to Intervene in Hungary-Ukraine Row", UNIAN, 27 May 2018, at <https://www.unian.info/politics/10132220-polish-fm-calls-on-nato-s-stoltenberg-to-intervene-in-hungary-ukraine-row.html>.

144 Gudmundar Alfredsson, "Identifying Possible Disadvantages of Bilateral Agreements and Advancing the 'Most-Favoured-Minority Clause', in Arie Bloed and Pieter van Dijk (eds.), Protection of Minority Rights through Bilateral Treaties: The Case of Central Eastern Europe (Kluver Law International, The Hague, 1999), 173; Emma Lantschner and Roberta Medda, "Protection of National Minorities through Bilateral Agreements in South-Eastern Europe", 1 EYMI (2001/2002), 535-561, 541. 
community. This counters the argument put forward by some scholars that no minority community would be opportunistic enough to risk a conflict just to attract attention. ${ }^{145}$ Not all conflicts are of a violent nature and not all stakeholders risk a lot by bringing one about. As the specific example of Ukraine and Hungary shows, kin-states can arrive at a position where a conflict is perceived as an acceptable price for enforcing human rights - especially if that goal cannot be achieved by other means.

Such bilateral conflicts could be avoided through a more proactive enforcement of human rights norms by international bodies. An international court enforcing minority rights through individual petitions of victims is a good example of a mechanism which would decrease the need for kin-state involvement. Alternatively, states with the right to initiate proceedings against another state might increase the activity of kin-states but would limit the conflict and channel it to a legal debate, which could be preferable to diplomatic hostilities. Even in the absence of new mechanisms, international bodies should increase their efforts to enforce minority rights, otherwise they create the space for bilateral tensions.

The current Ukrainian-Hungarian conflict has ultimately two basic solutions: (1) Hungary could withdraw its opposition to the Ukrainian law, perhaps after some compromise implementing legislation is passed or (2) Ukraine could amend its law to bring it into compliance with its international obligations. The former legitimizes a violation of international human rights norms, which are sure to resurface again in the future. Only the latter could achieve a long-lasting absence of tensions between the Ukrainian state, its minority communities and their kin-states.

The lack of enforcement of minority rights mechanisms not only undermines the goal of human rights treaties, it also undermines the goal of conflict prevention mechanisms, by creating perverse incentives to capture the interest of the international community by presenting minority concerns as issues of security. This is a double-edged sword for the concerned minorities, and a double loss for the international community. However, in the absence of effective alternative mechanisms, this can be an effective tool at the disposal of kin-states with a view to enforcing international norms on minority rights.

The year 2018 was a reminder of how minority rights can still lead to grave tensions in and between European countries. The conflict is far from over, and

145 Natalie Sabanadze and Vincent de Graaf, "Are Some States and Minorities More Equal Than Others? Double Standards and the Work of the osce High Commissioner on National Minorities", in Kristin Henrard (ed.), Double Standards Pertaining to Minority Protection (Martinus Nijhoff Publishers, Leiden, 2010), 117-143, at 133. 
will probably occupy headlines in 2019 as well. It remains to be seen whether, if not the parties involved, then the international community will learn from this year's developments, and address the situation created by the Law on Education. It would be to the benefit not only of Hungary, Ukraine, and the minority communities living there, but also to the integrity of the European minority protection system. 
